\title{
VALUATION OF INTANGIBLE STREET RAILWAY PROPERTY
}

\author{
By Frank R. Ford,
}

Of Ford, Bacon \& Davis, Consulting Engineers, New York City.

The intelligent regulation of street railway fares, taxation, capitalization and service depends upon the possession of accurate information concerning the value of the property under investigation. Without this knowledge, the governmental authority can do nothing more than form a more or less accurate guess as to the solution of the problem, based largely on ex parte testimony, and this, in some cases, will not be just to the company and in some, to the traveling public.

The importance of an accurate valuation of street railway property is now universally recognized. An examination of the history of the serious efforts to place a valuation upon street railway property discloses, in recent cases, a development in the methods of valuation, and the formulation of certain rules and practices which are now becoming standardized.

The valuation of tangible property is an engineering matter of comparative simplicity. An engineer of experience can ascertain, in detail, the expenditure required to duplicate a property having the same physical standards as the one under investigation.

The valuation of intangible property is more involved. The things to be valued are difficult to measure by definite standards, but must be appraised generally by indirect and, in many cases, by inductive methods.

In distinguishing between tangible property and intangible property of the street railway company, the publicly accepted method has been to call one physical property and the other franchises. A careful consideration of the subject, however, will show that there are other items besides franchises which should be included in the term "intangible property."

Physical property is fairly easy to label, inventory and value, so that, it is believed, a correct understanding of the term "intangible 
property" can best be had by subtracting from the total property that which is physical, or tangible.

\section{Tangible Property}

The physical, or tangible, property includes land, construction, equipment and cash, or its equivalent. If these items are being valued on the basis of either the original cost or the cost of reproduction, they should include the cost of acquiring land, the cost of supervision and administration of the construction by the general contractor, the sub-contractors, the engineers and the company's executive organization. In other words, all labor and expense going to make up the construction of the finished whole should be included, whether this labor be that of day laborers, foremen, superintendents, contractors, engineers or officers and employes of the company. The expenses of such construction work should also include all contingent expenses in connection with such labor, together with such items as interest and taxes during construction, and other overhead charges. In some cases the cost of acquiring land, the administration of construction work by the company's organization, the general contractor's services, engineering expenses and interest and taxes during construction have been considered as intangible property, this distinction being due, presumably, to the fact that in estimates of cost of reconstruction these items have been arrived at by the use of round percentages. Such labor and expense, however, are essential features of the cost of construction and equipment, and consequently belong, strictly speaking, to the tangible property. Stock, tools, supplies and working capital, in whatever form it exists, are also part of the tangible property.

$A$ list of the principal items which enter into the cost of production of the tangible, or physical, property comprises the following:

\section{Work and Expense Items Forming the Tangible Property of a Street Railway}

I. Company's overhead charges upon construction.

I. Executive organization's work and expenses, including:

a. Accounting expenses.

b. Office expenses.

c. Storeroom and stable expenses.

$d$. Permits of authorities and city inspection. 
2. Legal work and expenses.

3. Technical work and expenses.

a. Company's engineering organization.

$b$. Consulting engineers.

c. Architects.

$d$. Testing and outside inspection.

4. Interest during construction.

5. Taxes during construction.

6. Wear and tear during construction.

II. Land, including private right of way and sites for power-houses, car barns, shops, terminals, etc.

I. Assessed value.

2. Additional market value for ordinary purposes.

3. Additional value for railroad purposes, including:

a. Plottage.

b. Contiguity factor.

c. Special value for railroad purposes due to location.

4. Overhead charges for acquisition of land, such as:

a. Brokerage.

b. Legal work and expenses.

c. Technical work and expenses.

$d$. Title insurance.

e. Loss on portion of site not necessary.

$f$. Loss of buildings discarded.

III. General contractor's overhead charges and profits.

I. Work and expenses of contractor's general organization and office.

2. General superintendence, watching and lights.

3. Fire, accident ard liability insurance during construction.

4. Maintenance and use of tools.

5. General contractor's profits.

IV. Material and labor, comprising the physical construction and equipment, as furnished by the sub-contractors.

I. Inventory, priced on basis of sub-contracts.

2. Extras, incidentals and contingencies.

V. Stock, tools and supplies.

I. Inventory, priced.

2. Incidentals. 
VI. Working capital, including :

I. Cash on hand.

2. Accounts and bills receivable.

3. Prepaid accounts.

4. Land and buildings not used in operation.

\section{Intangible Property}

All of the remainder of the corporation's property should be considered. as intangible property.

From the standpoint of value, the intangible property represents the total value of the company from a business standpoint, less the value of its physical property. From a standpoint of cost, either first cost or cost of reproduction, the intangible property represents the cost of acquiring rights and capital for producing the tangible property and for placing the company in a potential position for doing business efficiently as a going concern.

\section{Intangible Property from the Standpoint of Cost}

From the standpoint of cost of production through the period of development, the intangible property will include many, or all, of the following items:

Work and Expense Items Through the Period of Development Forming the Intangible Property of a Street Railway

I. Promotion of the enterprise.

I. Work and expenses of promoter's organization.

2. Preliminary legal work and expenses.

3. Preliminary technical work and expenses.

a. Survey and location of line.

$b$. Estimates of construction cost and of income and expenses.

c. Preparation of prospectus.

4. Profits of promotion.

II. Corporate organization.

I. Legal work and expenses.

a. Incorporation.

$b$. Details of perfecting legal organization.

c. Form of securities.

d. Mortgages. 
2. Executive organization's work and expenses.

a. Directors', officers' and employes' work and expenses (until commencement of construction).

$b$. Office and general expenses (until commencement of construction).

c. Engraving securities.

d. Registration and certification of securities.

III. Franchises and consents (often under conditions of competition).

I. Property owners' options and consents (for location and for change of motive power).

a. Executive organization's work and expenses.

$b$. Legal work and expenses (vacations of injunctions, etc.).

c. Technical work and expenses (surveys, maps, etc.).

d. Payments for consents.

2. Franchises and consents of municipal authorities (including municipal legislature, mayor, borough presidents, commissioners of bridges, parks, docks, highways, water supply, sewers, etc.).

a. Executive organization's work and expenses.

$b$. Legal work and expenses.

c. Technical work and expenses.

d. Payments for franchises.

A. Lump sum.

B. Capital expenditures under governmental requirements for property, the title of which does not vest in the company, such as:

I. Grading and widening streets.

2. Removing sub-surface street obstructions.

3. Paving.

4. Track and overhead line constructed on municipal property, such as parks and bridges.

5. Change of location of track or line, due to governmental requirements.

3. Consent of state utilities commission.

a. Executive organization's work and expenses of present. ing project. 
b. Legal work and expenses.

c. Technical work and expenses.

4. Trackage, pole and other agreements with other public utility corporations.

a. Executive organization's work and expenses.

b. Legal work and expenses.

$c$. Technical work and expenses.

IV. Development of technical stanclards.

I. Past supersession and obsolescence, caused by:

a. Changes in the art, and experiments, such as:

A. Stage coaches.

B. Horse-car system.

C. Cable system.

D. Storage battery system.

E. Compressed air system.

F. Underground contact systems.

G. Gasoline motor system.

b. Improvements in the art, such as:

A. Large double-truck cars in place of small singletruck cars.

B. Introduction of prepayment and safety devices on cars.

C. Improved electric motors.

D. Improvement of grade and alignment of track.

E. Standardization of gauge.

F. Replacement of single track with double track.

G. Heavier rails of improved design.

H. Improved paving and foundation.

I. Steel instead of wooden poles.

J. Placing electrical conductors underground.

K. Fireproofing barns, shops and power-houses.

L. Replacing small belted and direct-connected engine units with large steam turbines, and other power-house improvements.

M. Alternating-current distribution, permitting power development from one large plant, in place of direct-current distribution from several small plants.

2. Piecemeal construction. 
3. Extra cost of construction, due to non-interference with operation.

4. Solidification of roadbed.

5. Adaptation of construction and equipment.

V. Development of company's business.

I. Losses of early operation.

2. Losses of outlying sections of line.

3. Perfection of executive organization and business methods.

4. Development of park amusement enterprises.

VI. Consolidation with and control of other corporations.

I. Corporate consolidation.

$a$. Executive organization's work and expenses.

$b$. Legal work and expenses.

c. Payments to state or city.

d. Payments for securities.

$e$. Tangible or intangible property of merged corporation which is superseded by consolidation.

2. Leases of other corporations.

a. Executive organization's work and expenses.

$b$. Legal work and expenses.

c. Payments to state or city.

3. Investments in securities of other corporations.

VII. Financing.

I. Work and expenses of promoter and associates in negotiation and underwriting.

a. Preliminary promotion syndicate or association.

$b$. Stock underwriting syndicate.

c. Bond underwriting syndicate.

2. Sale of securities.

a. Permission for issue from state, state commission or municipal authorities.

A. Executive organization's work and expenses.

B. Legal work and expenses.

C. Technical work and expenses.

b. Financial negotiations.

A. Executive organization's work and expenses.

B. Legal work and expenses.

C. Technical work and expenses. 
c. Payments of commissions to bankers and brokers, representing their work, expenses and profits.

d. Discounts on securities.

VIII. Patents and licenses.

I. Development of inventions.

2. Purchase of patents or licenses.

IX. Interest on work and expense items of intangible property until commencement of operation.

It may be questioned, however, whether a number of the above items should appear in the capitalization of the enterprise. In many cases they have been charged against early income or later profit and loss. As an established industry to-day, it would seem that the allowable return should be high enough to permit the gradual writing off of some of the features of original cost. It would not appear just, however, to present security holders to discredit or destroy capital which was fairly expended for these items, especially if the history of the corporation shows that after deducting profits commensurate with the return on other kinds of business, it would not have been possible to amortize this portion of the principal.

It will be noted that the cost of producing the "going concern" value is included in the above list under items such as "solidification of roadbed" and "adlaptation of construction and equipment," under the general heading of "development of technical standards," and also under the heading of "development of the company's business."

In considering the cost of reproduction new of the intangible property, some of the items in the above list disappear. A detailed treatment of this feature will appear below.

\section{Intangiblc Property From the Standpoint of Value}

In appraisals, whether for the acquirement of the property by the municipality, for the fixing of rates, or for the assessment of taxation, the value of intangible property has often loosely been referred to as the value of the franchises, and in such cases the term "franchises" will be understood as synonymous. with "intangible property," although, speaking accurately, the latter term includes much more than the former.

Typical instances of valuations of intangible property of street railway systems are furnished by the appraisals in Detroit in I899, 
Chicago in 1906, Cleveland in 1908 and 1909, and Detroit again in I9I0.

\section{The Detroit Strect Railway Commission Valuation of 1899}

One of the first valuations of American street railways took place in Detroit in 1899 , under which the State, through a commission headed by Gov. H. S. Pingree, proposed to authorize the city of Detroit to purchase the railways for municipal ownership and operation. The appraisal of the physical property was made by a board of experts, headed by Prof. M. E. Cooley, and totaled $\$ 8,000,000$. The value of the franchises was fixed by Prof. E. W. Bemis at $\$ 8,478,563$. His computation was made on the basis of capitalizing the net earnings for the remaining life of the franchises after allowing four per cent. annual increase of earnings and deducting four per cent. interest on the $\$ 8,000,000$ of physical value. In this case the ratio of this intangible value to the value of the physical plant was one hundred and six per cent.

\section{The Chicago Street Railway Valuation of 1906}

In the Chicago case the franchises for some parts of the track had expired, and for other portions lasted for various periods. The expert commission representing the city, headed by B. J. Arnold, apportioned the earnings of the system by franchise expirations on the basis of car mileage operated over each track franchise. The future gross earnings of the unexpired track franchises were then estimated on the basis of an assumed rate of growth of the business until the expiration of the franchises. From these were stibtracted the estimated operating expenses, including taxes, based on the present cost of operation. From the resulting net earnings was deducted interest at the rate of five per cent. on the estimated value of physical property corresponding with the franchise section, which physical property was proportioned in accordance with the car mileage operated over each franchise. The resulting net income of each franchise was then discounted as of the present date and capitalized at five per cent.

There was a dispute as to the length of the remaining franchises, and the valuations submitted to the City Council by its experts were based on various franchise periods from twelve months to thirty-six months. The total value finally agreed upon for all of these prop- 
erties was $\$ 50,000,000$, which corresponds most nearly with the value of the property if the franchises are given an average remaining period of eighteen months. On this basis the total value of the physical property, including paving, is $\$ 4 \mathrm{I}, 977,8 \mathrm{II}$, and the value of the intangible property $\$ 9,016,97 \mathrm{I}$, making a total value of $\$ 50,994,-$ 782. It will be noted that the value of the intangible property in this case is over twenty-one per cent. of the value of the physical property.

As a matter of fact, the proportion of intangible property in the final value was considerably more than this percentage, due to the fact that the cable systems were valued largely as going concerns. If the cable property, however, was valued according to its availability in converting these lines into part of an electric systen, there would be deducted from the physical value $\$ 4,794,6$ I 8 . $R e-$ ducing the physical value by this amount, and adding the same amount to the value of the intangible property, would result in values of physical property of $\$ 37,183,200$, and of intangible property of $\$ 13,811,582$, so that on this basis the intangible value represents over thirty-seven per cent. of the physical value.

The experts of the city also included in their physical property valuation an item of ten per cent. upon the total construction cost to cover the general classifications of (I) legal expenses, including those incurred in securing right of way and frontage consents; (2) interest during construction; (3) brokerage, or the expense of securing the necessary moneys; (4) contingencies and other items of expense. This allowance is generally believed to have been insufficient.

Part of these expenditures undoubtedly belong under the heading of intangible property, and if we assume that Items $r$ and 3 , or one-half of this ten per cent., were so classified, we add $\$ \mathrm{r}, 690,145$ to the intangible value, which thus becomes over forty-three per cent. of the physical value.

\section{The Clcucland Strect Railzay Valuations of 1908 and 1909}

In the Cleveland valuation of 1908 , the negotiations were conducted by Mayor T. L. Johnson, for the city, and F. H. Goff, for the company, and the physical valuations were made by committees headed by A. B. du Pont and H. E. Andrews. The value of the physical property, after deducting depreciation, was found to be 
$\$ 15,034,614$. This amount included a charge for the legal organization of the company, which should be classed as intangible property, amounting to $\$ 40,000$. Deducting this sum would leave the net physical value $\$ 14,994,614$. The value of the franchises and good will agreed to was $\$ 8,954,985$, to which we should add the abovementioned \$40,000, giving an aggregate total intangible value of $\$ 8,994,985$. In this case, therefore, the ratio of intangible to physical property was sixty per cent. This ratio is probably larger than it should fairly have been, as the physical value was unreasonably lowered and depreciated.

Judge R. W. Tayler, who was the arbitrator in the final settlement of this Cleveland valuation in 1909 , recognized this low estimate of physical value by increasing the estimate as of the same date (January I, I908) to $\$ 17,5$ I I,856. He reduced the intangible value, however, on that date by decreasing the franchise value to $\$ 3,615,844$, and eliminating entirely the item of "good will," and transferring the item of "going value" to the classification of "physical property." After shifting the \$40,000 of intangible value mentioned above from the physical to the intangible value, we find that the ratio of intangible to physical value is twenty-one per cent. This figure, however, would be further enlarged if it were possible to secure the details of certain items included by Judge Tayler in his physical value, inasmuch as he added a general overhead charge of fifteen per cent. to include a number of development expenses, some of which, such as financing, organization, consents and litigation with property owners, would come under the class of intangible property as above defined. It is probable, therefore, that the ratio, under Judge Tayler's valuation, is considerably over twenty-five per cent.

\section{The Detroit Street Railway Commission Valuation of I9Io}

The valuation of property of the Detroit United Railway, made in I9Io by the committee of fifty appointed by Mayor Philip Breitmeyer, has created much interest in the street railway world. This valuation of physical property was made by a number of experts, under the supervision of F. T. Barcroft, who found that the total value of the physical property was $\$ I I, I 2 I, 725$.

The valuation of unexpired franchises was made by Prof. $\mathrm{H}$. C. Adams, and amounted to $\$ 2,810,615$. This was based on the some- 
what inaccurate method used in the Chicago franchise valuation, of proportioning gross earnings by franchises on the basis of the car mileage operated over each franchise. It also allowed for no increase of gross and net earnings during the remainder of the franchises, which in some cases did not terminate for twenty-five years. The ratio of intangible to tangible property as thus developed is equal to slightly over twenty-five per cent.

Professor Adams also presents an estimate of the value of these franchises on the basis of assuming six per cent. increase of gross earnings per year of the unexpired term. On this basis the franchise value would be $\$ 4,246,208$, which would equal over thirtyeight per cent. of the physical value. This ratio, however, would seem to be somewhat larger than fairness would justify, as the valuation of the physical property made by the experts of the company was $\$ 24,676,182$, or more than double the Barcroft valuation.

\section{Intangible Property From the Standpoint of Cost of Reproduction New}

In order to view the subject of value of a street railway property from the standpoint of cost of reproduction, the usual method has been to endeavor to ascertain the cost of reproduction of the physical property, depreciated to present condition. For some uses, such, for instance, as in a rate case, it is believed to be fairer and more satisfactory to ascertain the cost of reproduction new of the entire property. This is the amount which a competing enterprise would cost to produce and upon which its rate of fare would be based. The public is not interested in the amount of depreciation of physical property if it is well maintained in condition to give good service. There would be an economic waste if such depreciation were repaired.

It has been suggested that the normal depreciation which is present in every operating property be regarded as an offset to the "going concern" value of the property. A street railway property, upon the commencement of operation, has to go through a period of adlaptation of the component parts of the physical construction and equipment, both as to each other and as to their joint uses in the business, whereby the mistakes of design and construction are eliminated. Similarly, the legal and executive organization of the company must be got into smooth and efficient working order, 
and furthermore, what may be most important, the business and income of the company must be developed through a period of at least several years to a point which will prove the success of the company as a profitable enterprise. This assurance of its technical, operating and business practicability is the "going concern" value of the property. If, therefore, the "going concern" value equals the amount of depreciation, we arrive again at the cost of reproduction new as an important and in some cases a controlling element in the valuation of a street railway property.

The items forming the cost of reproduction new of the physical property have already been considered. In order, however, to produce this tangible property, it is necessary to reproduce both the rights under which it is constructed and by which it may operate, and the financing which pays for the production of both tangible and intangible property.

For any given company or system we must imagine that the streets are clear of its tracks and that we begin with the inception of the enterprise in the mind of a promoter or business pioneer. This man and his associates, for the development of the enterprise up to the construction period, in the case of a large company, will employ a working force of lawyers, engineers and an executive organization. The securing of public rights and private capital, often under conditions of competition with other transportation interests, must be considered from the standpoint of local conditions, customs and laws.

\section{Inventory of Work and Expense Items of Reproduction of Intangible Property}

It is believed that the first instance that this theory has been worked out in careful detail was the Coney Island fare case of the Coney Island and Brooklyn Railroad Company, before the Public Service Commission of the First District (New York City). As technical advisers to the company, my firm there made up a list, or inventory, of the work and expense items comprised in the reproduction new of the intangible property of that company. This inventory, in brief, sets forth the time and expense items of all departments of the organization, of the promoter and of the company, first, during the promotion period, or time of obtaining rights and capital, and then during the construction period, or time of 
expenditure of capital, to the completion of construction. These items are separated as between the promoter's organization, the legal department and the technical department, through the preliminary development of the idea, the formation of the promoter's syndicate, the securing of the corporation's charter and the obtaining of its franchise from the municipal body and of its certificates from the Public Service Commission, together with the property owners' consents and those required from the minor city departments and other corporations. The time spent in connection with financing the enterprise is largely co-extensive with that of obtaining rights and comprises the various steps of underwriting and negotiating the sale of securities. After the franchises and capital are obtained, the construction period begins by the organization of the permanent working force of the company, and continues through the general administration of the construction work by this executive organization to the completion of construction. Fhis inventory, as submitted in the case, is reproduced on pages I34-I4O as Exhibit No. I.

\section{Time of Reproduction}

In order to determine the time spent on each part of this work, and the contemporaneous nature of a large part of it, there was prepared a chart of estimated time of reproduction sub-divided as between the various departments. The estimated time taken for each part of the work was based upon the actual time which has recently been required to secure similar rights in New York City under present legal restrictions. It was estimated that three and one-half years would be required from the inception of the project to the time that capital and rights would be obtained. The construction period was estimated, from instances of recent construction work, to require two years and ten months' additional time, making a total of six years and four months, although the beginning of partial operation was assumed to take place one year before the end of construction. The chart of estimated time of reproduction is shown opposite page I fo as Exhibit No. 2.

\section{Estimated Cost of Reproduction}

The number of men in each department and their rates of pay were then assumed, producing, when allowance had been made for general expense items, the total expenditure in each department and 
for each part of the work. All of this was, as far as possible, based upon actual similar work and expenditure of other corporations. The resulting estimated cost of each general item of the tangible and intangible property is shown in Exhibit No. 3 (page I4I).

In this case the ratio of intangible property to tangible property is $\$ 779,700$ to $\$ 8,520,198$, or slightly over nine per cent. There are, however, a number of items, such as profits of promotion, discounts and commissions on sale of securities, etc., which were specifically excluded in this estimate, as it was claimed that these items should be allowed for in a rate of return higher than the interest rate of six per cent., rather than in a principal value. For these items, the experts of the Public Service Commission estimated the minimum cost of reproduction at $\$ 976,490$, and the maximum cost at $\$ 1,973,938$, equivalent to over eleven per cent. and twenty-three per cent., respectively, of the above cost of reproduction of tangible property. The same reasoning would apply to other items for which no claims were made by either side, such as features of value of the present franchise of this company that cannot be reproduced, the cost of development of the business, represented by the deficiency below a reasonable return due to deficits of early operation, and the cost of development of technical standards, comprising obsolescence of the horse system and of the early electric system. If the rate of return on the valuation of the street railway property be fixed as low as six per cent., allowance should also be made for this class of expenditure of capital in the principal amount of cost of reproduction new.

In conclusion, it would appear from this general survey of the field of street railway valuation, that there are elements of value in the street railway property, whether called by the terms "intangible property," "franchises," "earning power," "good will" or "going concern," which can be measured by methods more or less exact, and which have been appraised in recent notable instances at from twenty-five per cent. to over one hundred per cent. of the value of the physical property. 